\title{
"Shale Revolution": Consequences for the World and Russia
}

\author{
Alexander F. Jinjolia ${ }^{1}$, Vladimir A. Kabanov ${ }^{1}$, Elena G. Popkova ${ }^{1} \&$ Larisa S. Shakhovskaya $^{1}$ \\ ${ }^{1}$ Volgograd State Technical University, Volgograd, The Russian Federation \\ Correspondence: Elena G. Popkova, 28, Lenina Avenue, Volgograd, 400005, The Russian Federation. Tel: \\ 7-844-224-8478. E-mail: 210471@mail.ru
}

Received: January 5, 2015 Accepted: February 3, 2015 Online Published: June 13, 2015

doi:10.5539/ass.v11n20p49

URL: http://dx.doi.org/10.5539/ass.v11n20p49

\begin{abstract}
Over the past few years, the attention of many Russian and foreign researchers has been focused on changes in the laws of functioning of the world gas market due to the phenomenon of shale revolution in the US. The most in depth analysis the following aspects of this problem were subjected to: economic and energy, economic and technical, environmental and geopolitical. Within the frameworks of analysis of the economic and energy aspect of the shale revolution, researchers have focused on the assessment of the economic consequences of this phenomenon for the world gas market and market of energy resources. This article presents a comprehensive author study of the consequences of the "shale revolution" for the world and for Russia.
\end{abstract}

Keywords: "shale revolution", shale gas, geopolitics, Russia, the United States

\section{Introduction}

Less than for a quarter of a century Russia has gone a way, which took other industrialized countries about four hundred years. Moreover, this way was infinitely more difficult than they had, because it assumed not progressive development within the same economic model, but a complete change of the economic paradigm of development: if the industrialized countries were perfecting the market economy for several hundred years, Russia which was developing administratively planned economic system for 74years, had to switch to a market economy almost overnight and, in that capacity, became involved in the international division of labour.

Participating in the international division of labour, each country exports those resources that it has in abundance to the world market. In Russia, basically, it turned out to be energy - oil and natural gas, which appeared to be very handy, because it was necessary not only to switch to a market economy, but to create a socially oriented market model of management. With increase of the energy prices in the end of the XXth century, all the surplus incomes from the export of cheap energy, especially natural gas, Russia has sent to the stabilization fund - a "safety cushion" in case of economic crises, and social programs for the population which can improve quality of life. Gradually, Russia became the largest exporter of natural gas, which was mainly supplied through pipelines in the EU and in the liquefied form in other countries. Naturally, such a dependence of the EU from Russian gas did not satisfy, first of all the United States, who were afraid of the growing influence of Russia, both in the world and in Europe.

\section{Materials and Methods}

The global and the Russian markets of shale gas stand as the object of this research.

In the US extraction of shale gas has developed over 20 years. During this period the technology of extraction, providing competitiveness of shale gas on the US gas market, in particular due to minimizing transportation costs for the delivery of products to the consumer, was developed. In 2012, extraction of shale gas has provided more than $8 \%$ of the total gas extraction of the US or more than 67 billion $\mathrm{m}^{3}$. The annual increase in production was $5.3 \%$.

According to the data of the US Energy Information Administration, by 2012 the extraction of shale gas in the US raised up to 240 billion $\mathrm{m} 3$, which allowed to refuse to import LNG from Qatar and to start making plans to export their own LNG to Europe and Asia-Pacific markets. As a result, due to the released capacities for exports to the United States shipments of LNG from Qatar to the European spot market gas significantly (by 17 times from 2003 to 2010) increased. 
The growth of production of shale gas in the US has led to the fact that in Europe there appeared expectations that in the near future expensive natural gas would be gradually replaced in the market by shale one, despite the fact that in the Western and Eastern Europe population density in areas of possible shale gas production in times higher than in the US. According to the opinion of American experts, large reserves of shale gas may be situated in Poland. Initially, it was assumed that it can be talked about 1.5-3 trillion $\mathrm{m}^{3}$ (according to some estimates even 5.9 trillion $\mathrm{m}^{3}$ ). Right after Poland reserves of shale gas were discovered in Bulgaria: in August 2010, geologists discovered a field of shale gas, resources of which are estimated between 6 and 8 billion $\mathrm{m}^{3}$. Nowadays Bulgaria consumes about 5 billion $\mathrm{m}^{3}$ of gas per year, imported by the country, mainly from Russia (Froggatt et al., 2012).

However, the recent estimates of the reserves made by the Polish Institute of Geology, appeared to be much more modest: according to them, the reserves shale gas in the country are within the range of 346 to 768 billion $\mathrm{m}^{3}$. However, this is enough to meet the needs of Poland for 35-65 years.

Along with Poland and Bulgaria, Romania the potential for commercial shale gas productions. In Western Europe, according to estimates of experts, Germany, France, Spain and the UK have significant reserves of shale gas. At the same time, a widely used here practice of moratoriums on development of deposits of shale gas makes it difficult to accurately assess reserves. All these countries in one way or another make efforts to deploy exploration and production of shale gas. Thus, in March 2013 Ministry of Finance of Great Britain announced introduction of tax incentives and adoption of measures which are to reduce public opposition to development of shale deposits and, in particular, to calm fears that the "technology of hydraulic fracturing triggers earthquakes and pollution of environment".

However, success the gas content in the rock being the same as in the richest deposits in the United States in order to cover the development costs, which appeared to be higher than it was originally assumed. According to the Shale Gas Europe group, supporting extraction of shale gas on the continent, the potential costs of mining companies in Europe are higher than in the United States. In the US, development of a well costs from 3 million to 11 million dollars, in Europe - from 8 million to 16 million dollars.

In March 2013 the US company Cheniere Energy Partners signed a contract for supply of LNG to the United Kingdom in the amount of 1.35 million tons a year since 2018. Previously, the British BP Group signed two contracts for supply of LNG since 2015, in the total volume of 5 million tons per year.

Besides that, in May 2013 there appeared reports that the largest oil company of the USA ExxonMobil with the help of experts from Qatar was going to build a plant in Texas on production of liquefied natural gas and a terminal for its export with a total value of 10 billion dollars. It is expected that the volume of supplies of LNG for exports would reach 15.6 million tons per year. A little earlier - in April - it was reported that ExxonMobil was also going to build a floating plant to produce LNG in collaboration with the Anglo-Australian mining company BHP Billiton. The costs on this project, according to experts, will exceed 12 billion dollars, and the capacity of the LNG plant will be about 6-7 million tons per year.

This can potentially increase the volume of gas supply in Europe in such a way, so that even without its own shale gas European consumers will be able to gain decrease of prices of Russian natural gas and reduction of its share in the European market. Of course, it will hit the export opportunities of "Gazprom". After all, at the moment $75 \%$ of revenue of the corporation accounts for the European market, and to reorient the trunk pipeline system for deliveries to other markets seems to be extremely difficult. Suffice it to recall the story with the construction main oil pipeline ESPO by the company "Transneft" in order to enter the markets of the APR. At present, the "Gazprom" is bound by major investment commitments (amounting to about 25 billion euros) for the construction of gas pipeline "South Stream" to bypass the Ukrainian gas transportation system. Therefore, the gas project, similar to the ESPO, in an easterly direction is hardly possible in the near future. Local "eastern" project of gas supply from the Chayandinskoye deposit through the main pipeline in the region of Vladivostok with building there by 2018 a plant for producing 10-15 million tons of LNG is obviously lagging because, according to some analysts, already 2016 could be a turning point.

The following data (see Table 1) show that satiety of the European gas market has become. Information about the continuing recession in the European economy and the EU's plans to increase energy conservation and energy efficiency of the economy allow to suggest that the negative trends in development of export of Russian gas would remain in the medium and possibly in the long term prospects. From 178.4 billion $\mathrm{m}^{3}$ in 2012, Europe has been exported 138.8 billion $\mathrm{m} 3$, compared with 2011, this figure decreased by $8 \%$. 
Table 1. Export of natural gas from Russia

\begin{tabular}{cccccccc}
\hline Indicator & 2006 & 2007 & 2008 & 2009 & 2010 & 2011 & 2012 \\
\hline Valuable volume, billion US dollars & 43.8 & 45.2 & 69.1 & 42 & 47.4 & 64.9 & 62.9 \\
Phizycal volume, billion m3 & 203 & 193 & 195 & 168 & 174 & 185 & 178 \\
\hline
\end{tabular}

Source: The shale revolution has prospects. DOI: $h t t p: / / d w \cdot d e / p / 197 q L$.

Though, the gas market of APR faces changes associated with the "shale revolution". For example, there are researches in five directions related to extraction of shale gas, developed in China. They, in particular, include:

- development of equipment for drilling gas wells;

- development of drilling mud;

- development of manufacture of auxiliary chemicals for extraction of gas, etc.

* According to the data of World LNG Report 2011.

These studies are designed to overcome the technological gap between China and the developed countries and to create their own database for extracting shale gas, "as well as would help to significantly reduce the cost-price of extraction of shale gas and to remarkably improve the successfulness of exploration" (Shale gaz..., 2011). The research is conducted in the Engineering School at the China National Petrochemical Company, Sinopec, which is currently conducting operation on extraction of shale gas in the Sichuan Basin in southwest China on an experimental basis (Shale gaz..., 2011).

Forecasts of the leading energy agencies and companies indicate that in the future the world will continue to increase natural gas production from non-traditional sources (see Table 2) (Nyquist \& Lund, 2014).

Table 2. Forecasts of non-traditional gas in the world

\begin{tabular}{llllll}
\hline Organization & 2015 & 2020 & 2025 & 2030 & 2035 \\
\hline BP, million tons & & 596.1 & & 1518.2 & \\
Energy Department of the USA, million tons & 475 & 577.5 & 722.5 & 895 & \\
International Energy Agency, billion tons & & 3982 & & & 5112 \\
\hline
\end{tabular}

Source: The shale revolution has prospects. DOI: http://dw.de/p/197qL.

It is also important to note that when it comes to the fate of the Russian state-controlled gas monopoly - OJSC "Gazprom", it is necessary to take into account the tendencies in the domestic gas market, in particular, negative for "Gazprom" increase the share of independent suppliers of gas to $25 \%$.

Despite such pessimistic for the Russian gas monopoly forecasts, it should be noted that the increase of gas consumption in Europe will continue at least until 2025 and can constitute up to $28 \%$.

The second factor that has a positive effect on the prospects for Russian gas deliveries to the markets of Asia-Pacific region is the consequences of a major accident at the nuclear power plant "Fukushima-1" in March 2011. Due to the tsunami "Fukushima-1" was deprived of electricity, which led to termination of cooling of the reactor, melting down of nuclear fuel and explosion. While extinguishing the fire there occurred significant releases of radiation into the sea and atmosphere. According to experts, elimination of consequences of the accident will take from 30 to 40 years. Nowadays, most of the nuclear reactors in Japan are stopped for an unscheduled inspection of their working capacity, reliability and safety. This led to a sharp increase of purchases of gas for thermal power plants, which cover the deficit of electricity and heat energy.

Besides that, there are serious obstacles in the way of gas exports from the United States. In particular, there is an industrial lobby in the US, which opposes the idea of gas exports. Large US companies, which are consumers of gas, claim that export growth will prevent them to gain benefits from low gas prices in the domestic market. Nowadays, the price of spot contracts in the US in Henry Hub (distribution hub in Louisiana, where eight largest US gas pipelines converge) is $140-150$ US dollars per $1000 \mathrm{~m}^{3}$. The price of gas in Europe is about 370 US 
dollars per $1000 \mathrm{~m}^{3}$, and the average price of a spot contract in the APR (the price of so-called "Japanese oil cocktail" - the index of Japan Crude Cocteil (JCC) is a benchmark for which) is now around 600 US dollars per $1000 \mathrm{~m}^{3}$, and in 2013 it exceeded even the bar of 800 US dollars per $1000 \mathrm{~m}^{3}$ (Ebinger et al., 2012).

This affects the position of the US Department of Energy, which, according to representatives of gas companies, delays with decisions on approval of applications for export of gas to the countries that do not have free trade agreements with the United States. The Ministry, in turn, states that in-depth studies must be made for each request, the results of which confirm that the export is beneficial for the United States. Nowadays there are 19 applications for the export of LNG under consideration by the US Department of Energy, but only two projects are approved so far. In particular, in May 2013 the application for export of LNG through the terminal of company Freeport LNG to the countries that do not have free trade agreements with the United States was approved.

Perhaps substantial support in the domestic market will be given to "Gazprom" by the Russian government. Anyway, in the middle of May 2013, the Russian government adopted a resolution about transferring to gas fuel of not less than $50 \%$ of public transport in the country. Despite the absence of specific terms of transition to use of gas, the government claims that the regulatory base for it will be prepared by the end of 2013. The Ministry of Industry and Transport Ministry got an order of the Prime Minister of the Russian Federation to reduce or even nullify the customs duties on components for production of gas fuel vehicles.

According to statistics, now in Russia only 100 thousand cars use gas for driving, although this type of fuel is both more ecological and economical than gasoline or diesel fuel. At that the number of vehicles with gas-motor fuel in 80 countries of the world reaches 17 million. According to the forecast of the Ministry of Energy, the number of gas fuel vehicles should grow by 25 times (to 2.5 million units) till 2030, and the number of gas stations by 17 times (from the current 200 to at least 3.5 thousand), which will allow to increase consumption of gas-motor fuel by 20 times in real terms. And this, in turn, will allow to reduce emissions by $12 \%$ and will bring the budget additional 5.3 billion dollars. It should be noted that the planned till 2030 level of gasification of vehicles is very mild: it does not exceed the forecast of AEB Automobile Manufacturers Committee for the annual car sales in Russia, which for 2013 is about 3 million units.

\section{Results}

The emergence of substitute products is a quite natural phenomenon for the market economy, which is a consequence of action of scientific and technical progress. At the same time, if this substitute is among the goods which are of the highest priority for development of the economy in whole, such a product, or the method of its production can become an alternative to the traditional good. The most striking example of this is shale gas, which is a substitute for natural gas and not only for its consumer properties, but also because of availability of technology and the apparent simplicity of its extraction, which has a significant impact on the structure of the global energy market, but it does not lead to a qualitative change due to rather low efficiency of the potential of all modern renewable technologies (Robart, 2012).

One of such energy sources, which have nowadays exceptional qualities of substitute products, is shale gas. Shale gas is a kind of natural gas stored in the form of small gas formations, reservoirs, deep in the shale layer of sedimentary rock of the Earth. Stocks of separate gas reservoirs are small, but they are huge in the aggregate and require special technologies for their development and production of gas (Hadro, 2010). The exclusive feature of shale gas is that it is not fundamentally different from traditional natural gas, however, the technology of its extraction and purification assumes more costs compared to traditional gas (Ridley, 2011).

Shale deposits are found on all continents and, thereby, virtually any energy-dependent country could potentially provide themselves with the necessary energy source. This energy source is currently of great interest in the world community. The main reason is to combine properties of fossil fuels and potentially renewable source in shale gas (The shale revolution..., 2014).

The known "shale revolution" ("shale boom"), in other words, the growth of global production of shale gas, can lead to profound changes in the energy balance in the world. That means, the use of the reserves of shale gas could help some countries to achieve the energy independence, to reduce or to stop the import of natural gas, or even to become exporters of hydrocarbons. Nowadays natural gas can be attributed to the most promising types of fossil fuel within the world energy supply, as its use assumes very low carbon dioxide emissions into the atmosphere, which is the cause of the greenhouse effect, and successfully replaces coal.

Development of extraction of shale gas in the modern world is stipulated by two interrelated reasons: economic and political. The first is constituted by the high real price cost of produced shale gas, more than while usual 
extraction of natural gas because of consequences for the ecology as a result of using hydraulic fracturing technology (by pumping under the pressure of tens of thousands of cubic meters of water, sand and chemicals into the well) during extracting shale gas. As a result of fracture gas enters through the fissures to the wellbore and then to the surface (Nyquist \& Lund, 2014).

The second reason - political is connected with the fear of a number of countries in the dominance of Russia in the global markets, due to the presence on its territory of huge deposits of energy, including natural gas - the "blue fuel", a relatively cheap and environmentally friendly. Many leaders of the countries, whose mentality has not overcome the era of the "cold war", still think it's not fair, why Russia should flourish and strengthen its economic and political influence, due solely to natural resources, rather than to the development of scientific and technical progress, which requires a much larger efforts and money? (Abiteboul, 2012).

Nowadays, the largest developer of deposits of shale gas in the world is the United States. Large-scale industrial production of shale gas began in America not so long ago, in the early 2000s. As a result of the rapid growth of the industry, in 2010 the United States ousted Russia from the first place in the world for the extraction of natural gas and, according to the International Energy Agency, by 2020, the United States may become the world's largest exporter.

According to official data, in 2013 the US became the world's largest producer of hydrocarbons (oil and gas), leaving behind Russia and Saudi Arabia. The American government has confirmed it in an official statement appeared at the beginning of October 2013, which said that the production of oil and gas in the country in 2013 will amount to nearly 25 million barrels of oil equivalent per day compared with 22 million in Russia and 13 million in Saudi Arabia (Energy from shale..., 2014).

In other words, the economic aspect of extraction of shale gas is enhanced by political considerations: a country that would take the main share of natural gas producer in the global energy market in the near future would determine the price of the resource and trade the technology of its production. Thus, production of shale gas in the US has already had a negative impact on the economic situation of the Russian gas companies and, primarily, of OJSC "Gazprom". In 2012, development of the Shtokmanskoye field was kept on ice, development of the Sakhalin shelf is questionable, because the produced gas was expected to be delivered in the US. The world market is a unit and increase of supply of gas in one region had naturally led to decline of world prices for gas. As a result of decrease of prices "Gazprom" has missed a large part of the profit, and the federal budget in the form of tax revenues with it.

\section{Discussion}

No matter how attractive today is the idea of an independent power supply each country with natural gas, it seems to us to be little realized under the present conditions and that is why. Beside economic and political factors, influencing the decisions on production of shale gas, there is another factor - ecological, which, in our opinion, at the moment prevails over the other two. This is an exceptional harm to the environment - the territory and the people who live on it, generated by extraction of shale gas. Thus, territories of the United States, where it is extracted, are not more suitable for any agricultural land use and safe living. Not by chance within the United States a number of states have recently passed a law banning extraction of shale gas on their territory (for example, New York state) (Cathles et al., 2012).

Ecological threat is the main limiter of extraction of shale gas in densely populated countries, where the density of living population is very high. For example, it would become a disaster for the EU, although the idea of energy self-sufficiency and further independence from Russian gas seems to them quite attractive, provided that shale gas will be produced not in their territories. Due to the fact that the European countries do not own the technology of extraction of shale gas, the decision on their energy independence from Russia was taken not by them, but by the United States, which intend to produce shale gas to the countries of the EU, but not in the densely populated European Union, but in Ukraine - the territory of the South-East of this country has huge deposits of it. Today, there are located coal mines of Donbass, which to a great extent have already exhausted their resources.

In the South-East of Ukraine, till recently, there lived about 5 million people and, of course, while getting ready for extraction of shale gas in these places, it would be necessary to clean the area from "excessive" population, leaving only those residents who would be directly linked to its extraction. There is one more negative consequence of the potential development of shale gas in the South-East of Ukraine is vast amounts of ruined fertile land, the so-called "Lebedinskii chernozems" which are kept in the Museum of Soil Science in Paris as a benchmark of fertile land. Ukraine, which was just 25 years ago called the "breadbasket" of the Soviet Union (producing bread for the whole USSR), and for which the wheat is still one of the most important export 
products, will lose this status. Moreover, left without wheat, Ukraine is unlikely to feed itself, endangering its food security.

Meanwhile, the US interest under the pretext in ridding the countries of the EU of energy dependence on Russia does not have any solid basis:

1) Russian natural gas is cheaper than shale gas produced today, and if to add here also the ecological component, then this burden for the EU can turn out to be very heavy;

2) The price of Russian natural gas to its customers in all countries of the world has always been negotiated, and with emergence of a competitive source of energy, it can be reduced even further;

3) Development of scientific and technical progress will always lead to emergence of substitute products, but that does not mean that rushing to limit the influence of one of the players of the market, we have to savagely withdraw whole territories from the land-use: the number of people on planet earth is growing rapidly, and it should live somewhere. An example of such a gentle, civilized attitude to its territory is China: owning large areas, it prefers cheap Russian natural gas to extraction of shale gas on them, and, thus, is not afraid that Russia's influence on its economy would intensify, preferring extraction and transportation of natural gas into its territory together with Russia.

\section{Conclusion}

Thereby, the effect of increasing deliveries of shale gas to the global energy market will have a pronounced regulatory nature, the degree of impact on the regional markets will be very different, and very impact would be determined by various factors due to the unique characteristics of each market.

Such phenomena would lead to some geopolitical shifts, but the overall changes of the energy structure of the market and relevant political processes would take place only with condition of illiterate economic policies of major gas players: 1) absence of work on improving technologies of shale gas production in order to eliminate environmentally harmful effects of its production; 2) absence of activities of Russian companies producing traditional gas companies on reduction of costs of its production and transportation to the final consumer (Stevens, 2012).

Emergence of substitute products in the gas market would have a corrective impact on its price and, in general, would lead to its decline, but presence of gas infrastructure in Europe, use of market regulators by OJSC "Gazprom" allows thinking that, despite the claims of many experts about the uncertainty of the global gas market, the situation is quite specific (Tollefson, 2012).

The regulatory impact of shale gas on the world markets really should not be discounted. Shale gas in future periods may provide large reserves of natural gas in some countries, leading to a significant change in the elasticity of demand in all micromarkets, including the European one (Wood, 2011).

At the moment, the policy of "Gazprom" should foresee a change in priorities: if earlier "gas lever" was an effective both economic and political mechanism, nowadays it is necessary to focus on the economic principles of the market management. Otherwise, the reason for the decline of the global impact of OJSC "Gazprom" would be not the very appearance of shale gas, but the reduction of the share in the global market of traditional gas (Shale gaz..., 2011).

In Russia, shale gas is not extracted and the prospects for its further development are while unlikely, though, according to the opinion of Academician Alexei Yablokov, shale gas could become an alternative to nuclear power plants in some parts of the world, which would lead our country to a new level of development through its own development of STP in all sectors, including its energy sources (Ecological results..., 2012).

\section{References}

Abiteboul, J. (2012). What is the Time Line for LNG Exports from the USA? Presentation to the Flame Conference in Amsterdam, 18 April.

Cathles, L. M., Brown, L., Taam, M., \& Hunter, A. (2012). A Commentary on "The Greenhouse Gas Footprint of Natural Gas in Shale Formations" by R.W. Howarth, R. Santoro, and Anthony Ingraffea. Climatic Change, 113. http://dx.doi.org/10.1007/s10584-011-0333-0

Ebinger, C., Massy, K., \& Avasarala, G. (2012). Liquid Markets: Assessing the Case for US Exports of Liquefied Natural Gas. Policy Brief 12-01, Brookings Institution, Washington, DC, May.

Ecological results of the year. Retrieved from http://www.yabloko.ru/news/2012/01/10_0

Energy from shale. America's energy. Retrieved from http://www.energyfromshale.org 
Froggatt, A., Mitchell, C., \& Manaqi, S. (2012). Reset or Restart? The Impact of Fukushima on the Japanese and German Energy Sectors. Chatham House Briefing Paper, July.

Hadro, J. (2010). Shale gas exploration strategy. Przeglad Geoljgiczny, 58(1), 250-258.

Nyquist, S., \& Lund, S. (2014). Shale revolution: opportunity to jump economic Growth. Retrieved from $\mathrm{http}: / / \mathrm{www}$. forbes.com/sites/realspin/2014.

Ridley, M. (2011). The Shale Gas Shock. GWPF Report 2, Global Warming Policy Foundation, London.

Robart, J. (2012). Water Management Economics in the Development and Production of Shale Resources. IAEE Energy Forum, First Quarter 2012.

Shale gas: myths and prospects of production. Retrieved from http://pronedra.ru/gas/2011/12/23/slancevyj-gaz/

Stevens, P. (2012). The Arab Uprisings and the International Oil Markets. Chatham House Briefing Paper, February.

The shale revolution has prospects. Retrieved from http://dw.de/p/197qL

Tollefson, J. (2012). Air Sampling Reveals High Emissions from Gas Field. Nature, 482(9), 15-18. http://dx.doi.org/10.1038/482139a

Wood, R., Gilbert, P., Sharmina, M., Anderson, K., Footitt, A., Glynn, S., \& Nicholls, F. (2011). Shale Gas: A Provisional Assessment of Climate Change and Environmental Impacts. Tyndall Centre Technical Reports.

\section{Copyrights}

Copyright for this article is retained by the author(s), with first publication rights granted to the journal.

This is an open-access article distributed under the terms and conditions of the Creative Commons Attribution license (http://creativecommons.org/licenses/by/3.0/). 